\title{
Power Of Test Path Analysis and Partial Least Square Analysis
}

\author{
Arif Kurniawan', Loekito², Solimun³ \\ Faculty Of Mathematics And Natural Sciences ${ }^{1,2,3}$ \\ Brawijaya University Malang \\ Email: arkur111@gmail.com, arkur112@gmail.com, arkur113@gmail.com
}

\begin{abstract}
Path Analysis and Partial Least Square (PLS) was used to analyze many variables. Both methods use the least squares method (OLS) that can be compared between the two to determine the best method in a study to get an assessment of the behavior of civil servants in the Government of Kediri. The purpose of this study is comparing path Analysis with Partial Least Square (PLS) on the power of the test and the value R2. Path method is able to provide the value of R2 higher than Analysis of Partial Least Square (PLS) also the value of the test power analysis path is higher than using Analysis of Partial Least Square (PLS). Usage analysis methods Path Analysis and Partial Least Square (PLS) produces behavioral assessment of civil servants in the government of Kediri is nearly equal results and discussion. Based on the analysis to prove that the behavior of civil servants in the Government of Kediri not meet eligibility based on the grade levels and echelons of the civil service.
\end{abstract}

Keywords: Partial Least Square, Least Square, Path method.

\section{INTRODUCTION}

Problems that exist in the world of work are many and complex, most of it is not simple and only includes a direct causal relationship. Regression analysis is a statistical analysis that has been widely known and easier understanding, use and application. Regression analysis can be used to determine the relationship of more than 2 variables but in the regression analysis has met some of the assumptions in advance that multicollinearity, heteroscedasticity, autocorrelation and normality.

Path analysis basically have a broader scope than the regression analysis which can both be used to analyze more than two points (variables), which has a form of certain relationship. Path analysis can determine the influence of the independent variables relationships dependent variable either directly or indirectly directly. Partial Least Square (PLS) Analysis was used to estimate the more complex models involving latent variables (variables measured from the other variables are indicators). The existence of variables that influence and are influenced other variables show a causal relationship between more than two variables.

Path Analysis and Partial Least Square can create a diagram that connects between several independent variables and some dependent variable. Therefore, the use of Path Analysis and Partial Least Square is appropriate to analyze a problem that has many variables [1]. The problems in this study is whether there is a difference between the power of the test and R2 Path Analysis with Partial Least Square Restrictions problem in this research is the use of a formative model with variables observed. The objectives of this research are Comparing Authorization Test between Path Analysis with Partial Least Square, is there a difference between Path $\mathrm{R}^{2}$ Analysis with Partial Least Square, how do the results of behavioral assessment of civil servants working in the city government of Kediri. 
The benefits that can be achieved through this research are Powerful Test Shows difference between Path Analysis with Partial Least Square, Shows the difference R2 Path Analysis with Partial Least Square, Shows the working behavior of civil servants in the Government of Kediri. Work behavior in the organization cannot be separated from four things: cooperation, integrity, commitment and discipline. Commitment good work will improve work habits, as well as the level of cooperation, discipline and integrity held by workers within an organization. So, the value of work behavior obtained from the overall value of collaboration, integrity, commitment and discipline [2].

\section{METHODS}

Data of the study include primary data about the behavior of employment and length of employment of civil servants, secondary data on the length of service, basic salary per grade and salary allowances echelon Primary PNS. Data obtained by collecting data directly at the sites. Data were collected through interviews to civil servants in Kediri City Government as well as through direct observation, so that the research data that will be obtained is accurate and up to date. In addition to the primary data used, this study also used secondary data is data compiled from existing data. Implementation of research conducted in the area of research time Kediri City Government in February to March 2016

Sampling for civil servants structural in city government Kediri done randomly as many as 97 people, using the formula $n=\frac{N}{1+N \alpha^{2}}$, where $N$ is the number of population is the number structural civil servants in Kediri city government as much as 3,234 people with $\alpha=0.1$.

\section{RESULTS AND DISCUSSION}

Significant relationships shown in endogenous variables basic salary per class and work behavior, while the effective working time is not significant. It is clear that the higher the grade and salary of civil servants in the town of Kediri government does not guarantee increasing the effective working time of civil servants in carrying out its duties. It can be said that civil servants in the town of Kediri based on the career paths and salaries amounted to only 3.5\% of civil servants who work in a professional manner, namely by increasing the effective working time. The strong influence on civil servants to work Behavior of Kediri only given by the effective working time with a value of 0.797 while the period of employment, and salary below 0.5 , meaning that the higher salary and years of service does not guarantee provides work behavior is increasing. This applies to civil servants in the government of Kediri.

it can be seen that all the behavioral indicators of civil servants working in Kediri City Government have a significant influence. This suggests that the scoring system is better done by colleagues in other words co-workers could be involved in addition to official appraiser or supervisor in work behavior assessment system of civil servants. In summary PLS results indicate that there are four significant influence with a confidence level of 0.05 , namely : the influence of effective working time on work behaviors with $\mathrm{p}$ value $=0.000$, the effect of tenure on the behavior of working with $\mathrm{p}$ - value $=0.043$, the effect of salary subject to the behavior and working with $p$ - value $=0.017$ and the effect of tenure on the basic salary bracket with a $p$ - value of 0.000 . The results of analysis by using path analysis and partial least square ( PLS ) analysis provides a discussion of analysis results are almost the same but the value is not the same calculation. To determine the value of better calculation between the two can be seen by comparing the value of $\mathrm{R}$ and the power of the test as follows :

Based on the research that the above comparison shows that $\mathrm{R}^{2}$ on Path Analysis produces a value greater than the PLS Analysis. This proves that in this study the use of Path Analysis is better than the use of PLS Analysis. 
Table 1. Compare R² Path Analysis and PLS Analysis

\begin{tabular}{|c|l|r|r|}
\hline No. & \multicolumn{1}{|c|}{ variable } & \multicolumn{1}{c|}{$\begin{array}{c}\text { Path } \\
\text { analysis }\end{array}$} & PLS analysis \\
\hline 1. & $\begin{array}{l}\text { the period of employment, basic salary, salary } \\
\text { allowances echelon, the effective working time } \\
\text { to work Behavior }\end{array}$ & 0,699 & 0,599 \\
\hline 2. & $\begin{array}{l}\text { the period of employment, basic salary, salary } \\
\text { allowances echelon to the effective working } \\
\text { time }\end{array}$ & 0,035 & 0,005 \\
\hline 3. & the period of employment to basic salary & 0,778 & 0,599 \\
\hline
\end{tabular}

Power comparison test on the response variable indicates that the power test on Path Analysis produces a value greater than the PLS Analysis. This proves that in this study the use of Path Analysis is better than the use of PLS Analysis of the power of the test.

Table 2. Compare Power of Test Path Analysis and PLS Analysis

\begin{tabular}{|c|l|r|r|}
\hline No. & \multicolumn{1}{|c|}{ variable } & Path analysis & \multicolumn{1}{|c|}{$\begin{array}{c}\text { PLS } \\
\text { analysis }\end{array}$} \\
\hline 1. & $\begin{array}{l}\text { the period of employment, basic salary, salary } \\
\text { allowances echelon, the effective working time } \\
\text { to work Behavior }\end{array}$ & 0,999778 & 0,999655 \\
\hline 2. & $\begin{array}{l}\text { the period of employment, basic salary, salary } \\
\text { allowances echelon to the effective working } \\
\text { time }\end{array}$ & 0,985788 & 0,897423 \\
\hline 3. & the period of employment to basic salary & 0,999853 & 0,999655 \\
\hline
\end{tabular}

\section{CONCLUSION}

The conclusion of this study is the use path analysis provides better value than PLS at R ${ }^{2}$ value and in terms of the power of the test. Behavioral conditions of work of civil servants in Kediri City Government did not follow the rules of the science of human resources in terms of election officials echelon structural or civil servants. Advice that can be given is a benchmarking test $\mathrm{R}^{2}$ and the power to use a sample model of a broader research eg civil servants in the province in order to obtain a very significant research model with population models .

\section{REFERENCES}

[1] Akter, A., D’ambra, J., Ray, P., An Evaluation of PLS based complex models: the roles of power analysis, predictive relevance and Gof Index. 2011.

[2] Leka, S., Griffiths, A., Cox, T., Work Organisation \& Stress. University of Nottingham. 1999. 